УДК 633.521:631.373:629.3.013

(C) А.С. Лімонт, к.т.н.

Житомирський агротехнічний коледж

3.А. Лімонт

Технічний ліцей при Дніпропетровському національному

університеті залізничного транспорту

\title{
ПИТОМА ВАНТАЖОПІДЙОМНІСТЬ І МАСА ТРАКТОРНИХ ПРИЧЕПІВ ЯК ЗАСОБІВ ТРАНСПОРТУВАННЯ ЛЬОНОТРЕСТИ
}

\begin{abstract}
Досліджені розподіли номінальної $і$ питомої вантажопідйомності тракторних причепів. Вивчена $i$ проаналізована маса циих транспортних засобів. Висвітлено статистичний зв'язок питомої вантажопідйомності $i$ маси тракторних причепів.

ЛЬОНОТРЕСТА, ТРАНСПОРТУВАННЯ, ТРАКТОРНІ ПРИЧЕПИ, ВАНТАЖОПІДЙОМНІСТЬ, МАСА, КОРЕЛЯЦІЯ, РЕГРЕСІЯ
\end{abstract}

Постановка проблеми. За рулонної технології збирання льонотрести [1] на перевезенні рулонів 3 поля до місць зберігання льоносировини чи пунктів їі первинної переробки крім інших транспортних засобів використовують i тракторно-транспорті агрегати (ТТА) у складі тракторів різного класу та тракторних причепів відповідної вантажопідйомності чи тракторні поїзди. Проте в проблемі транспортного забезпечення збирання рошенцевої льонотрести поки що залишилася ще нез'ясованою низка питань. Про деякі з них і йтиметься в цьому повідомленні.

Аналіз останніх досліджень i публікацій. Одним iз найважливіших параметрів тракторних причепів, що визначає їх споживчі властивості, є вантажопідйомність. 3'ясуванню вантажопідйомності транспортних засобів на перевезенні сільськогосподарських вантажів присвячені праці акад. М.Е. Мацепуро [2] та проф. Ф.С. Завалішина [3], Н.К. Діденка [4] і А.Д. Семковича [5]. Орієнтуючись на існуючі конструкції тракторних причепів в праці [6] відшукані кореляційно-регресійні

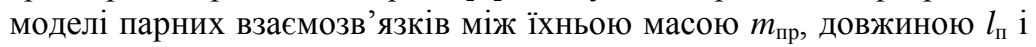

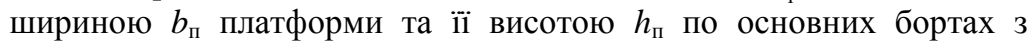
одного боку i номінальною вантажопідйомністю $q_{\text {н }}$ причепів 3 другого, а також зворотні зв'язки між вказаними параметрами. Доведено, що зміна $m_{\text {пр }}$ і $l_{\text {п }}$ залежно від $q_{\text {н }}$ та $q_{\text {н }}$ від $m_{\text {пр }}$ i $l_{\text {п }}$ 
описується рівняннями прямих 3 додатними кутовими коефіцієнтами, зміна $h_{\text {п }}$ від $q_{\text {н }}$ - рівнянням зростаючої степеневої

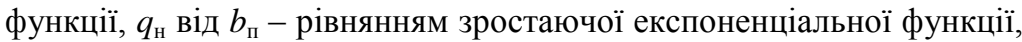
a $b_{\text {п }}$ від $q_{\mathrm{H}}$ і $q_{\mathrm{н}}$ від $h_{\text {п }}-$ рівняннями сповільнено зростаючих гіпербол.

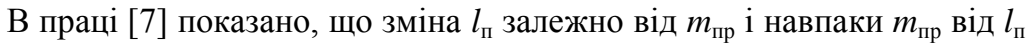
описується рівняннями прямих 3 додатними кутовими коефіцієнтами, $b_{\text {п }}$ від $m_{\text {пр }}$ і $m_{\text {пр }}$ від $b_{\text {п }}$ - рівняннями відповідно сповільнено зростаючої гіперболи і зростаючої експоненти, а зміна $h_{п}$ від $m_{\text {пр }}$ і $m_{\text {пр }}$ від $h_{\text {п }}$ описуються відповідно рівняннями сповільнено i прискорено зростаючих степеневих функцій. Одержані модельні рівняння регресії можуть бути використані при розрахунках 3 комплектування ТТА та проектуванні організації вантажоперевезень взагалі і зокрема транспортування льонотрести.

Дослідження енергомісткості TTA на перевезенні льонотрести залежно від вантажопідйомності причепів показало [8], що найбільш інтенсивно зменшується енергомісткість ТTА 3 підвищенням вантажопідйомності від 2 до 4 т, а 3 подальшим підвищенням вантажопідйомності до 10 т і більше енергомісткість TTA зменшується менш сповільнено. Використання на перевезенні трести великотоннажних причепів, що перевищують $q_{\mathrm{H}}=10 \mathrm{~T}$, має бути обмеженим.

Крім з'ясованих кількісних залежностей між наведеними масовими і розмірними параметрами тракторних причепів варто мати відомості щодо оцінювання їх вантажопідйомності 3 урахуванням маси транспортних засобів. Для цього визначено питому вантажопідйомність як відношення піi номінального значення до маси причепа.

Мета дослідження полягала у 3'ясуванні питомої вантажопідйомності тракторних причепів як передумови щодо їх проектування i розрахунку основних параметрів. Завдання дослідження: 1) сформувати статистичні вибірки вантажопідйомності i маси тракторних причепів виробництва підприємствами в межах колишнього СРСР і підприємствами поза межами колишнього СРСР та розрахувати їх питому вантажопідйомність; 2) проаналізувати питому вантажопідйомність тракторних причепів; 3) оцінити зв'язок питомої вантажопідйомності i маси тракторних причепів та виявити кількісну зміну питомої вантажопідйомності тракторних причепів залежно від їх маси.

Об’єкт дослідження - технологічний процес транспортування льонотрести 3 оцінюванням масових параметрів тракторних причепів. В якості масових параметрів причепів 
прийняті їх номінальна i питома вантажопідйомність та маса досліджуваних транспортних засобів. Методика пошуку вихідних даних щодо визначення масових параметрів тракторних причепів та методика опрацювання зібраних статистичних даних наведені в попередніх публікаціях одного з авторів цього повідомлення.

Результати дослідження. Досліджувані причепи були розділені на дві групи (статистичні вибірки), в першу з яких входили причепи виробництва підприємствами колишнього СРСР, а в другу - підприємствами поза його межами. Перша вибірка включала 15 марок причепів, а друга - 21. Розподіли номінальної вантажопідйомності причепів першої i другої груп характеризувалися розмахом варіювання відповідно 2-13 і 5-24 т, а їхні середні арифметичні значення і середні квадратичні відхилення дорівнювали в тій же послідовності 6,0 і 3,3 та 13,2 і 6,0 т. Розмах варіювання маси причепів першої і другої груп становив відповідно 0,7 - 6,34 і 1,2 - 7,1 т за середніх арифметичних значень і середніх квадратичних відхилень 2,8 і 3,6 та 2,1 і 1,6 т.

Питома вантажопідйомність причепів першої групи коливалася в межах $1,85-2,83$, а другої від 3,38 до 5,50. Середне арифметичне значення та середне квадратичне відхилення розподілу питомої вантажопідйомності причепів першої групи дорівнювали відповідно 2,27 та 0,30, а причепів другої - 4,29 та 0,58. Порівняння середніх арифметичних значень питомої вантажопідйомності двох груп вибірок причепів здійснили 3 використанням $t$-критерію Стьюдента [9]. Виявилося, що розрахований $t$-критерій 3 урахуванням помилок середніх арифметичних значень питомої вантажопідйомності відповідних вибірок дорівнював $t_{\mathrm{p}}=13,48$. Табличний $t$-критерій за числа степенів вільності $v=30$ на рівні значущості $\alpha=0,05$ становив $t_{\mathrm{T}}=$ 2,08 . Оскільки $t_{\mathrm{p}}=13,48>t_{\mathrm{T}}=2,08$ при $v=30$ i $\alpha=0,05$, то середні арифметичні значення питомої вантажопідйомності 2,27 і 4,29 значущо відмінні на рівні ймовірності 0,95 .

Проаналізуємо досліджувані сукупності за їх мінливістю 3 використанням визначених середніх квадратичних відхилень відповідних розподілів за $F$-критерієм Фішера [9], що являє відношення більшої дисперсії до меншої. За розрахунками спостережуваний (розрахунковий) $F$-критерій становив $F_{\mathrm{p}}=3,7$, а табличне значення $F$-критерію при числі ступенів вільності чисельника $v_{1}=20$ і знаменника $v_{2}=14$ на рівні ймовірності $P=$ 0,95 дорівнює $F_{\mathrm{T}}=2,4$ [9]. Оскільки $F_{\mathrm{p}}=3,7>F_{\mathrm{T}}=2,4$ при $v_{1}=20$ i $v_{2}=14$ на $P=0,95$, то дисперсії досліджуваних сукупностей питомої вантажопідйомності причепів відрізняються значущо i 
відмінні з ймовірністю, що перевищує $P=0,95$. Отже, порівнювані дві сукупності питомої вантажопідйомності тракторних причепів виробництва підприємствами колишнього СРСР і що знаходяться за його межами відрізняються одна від іншої не тільки середніми арифметичними значеннями, але i середніми квадратичними відхиленнями.

Між питомою вантажопідйомністю тракторних причепів першої та другої груп і їхньою масою виявлений від'ємний кореляційний зв'язок з коефіцієнтами кореляції $r$ відповідно мінус 0,701 і мінус 0,434 за кореляційних відношень $\eta$ результативної ознаки по факторіальній в попередній послідовності 0,725 і 0,434. За розрахованими показниками кореляційного зв'язку із збільшенням маси тракторних причепів їхня питома вантажопідйомність зменшується. Для з'ясування характеру цього зменшення здійснили перевірку прямолінійності за $t$-критерієм Стьюдента [10]. Перевірка показала, що при визначених коефіцієнтах кореляції i розмірах статистичних вибірок спостережувані (розрахункові) значення $t$-критеріїв стосовно причепів першої і другої груп становили відповідно 3,54 і 2,10 тоді як табличні $t$-критерії для вказаних груп причепів за таблицями квантилів $t$-розподілу [10] становили в тій же послідовності 2,16 і 2,09 . Оскільки для досліджуваних розподілів витримується умова $t_{\mathrm{p}}$ $>t_{\mathrm{T}}$, то лінійні моделі регресії питомої вантажопідйомності обох груп причепів на їхню масу узгоджуються з експериментальними даними. 3 використанням стандартних комп'ютерних програм здійснено вирівнювання експериментальних значень питомої вантажопідйомності причепів залежно від їх маси рівняннями прямих з від'ємними кутовими коефіцієнтами, рівняннями спадних степеневих, логарифмічних $\mathrm{i}$ експоненціальних функцій та гіперболічних залежностей. За $R^{2}$-коефіцієнтами найкраще наближення експериментальних значень питомої вантажопідйомності до вирівняних забезпечила їх апроксимація рівняннями прямих 3 від'ємними кутовими коефіцієнтами. На рисунку наведені кореляційні поля «питома вантажопідйомність $\lambda_{\mathrm{q}}$

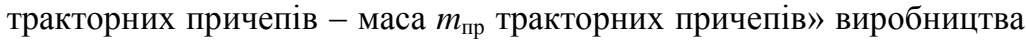
різними підприємствами та модельні лінії прямолінійної регресії $\lambda_{\mathrm{q}}$ на $m_{\text {пр. }}$.

Модельні лінії прямолінійної регресії, що наведені на рисунку, побудовані за такими рівняннями, які кількісно списують

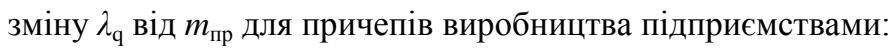

- колишнього СРСР: 


$$
\lambda_{\mathrm{q}}=2,63-0,133 m_{\text {пр }}
$$

при $r=-0,701 ; \eta=0,725 ; R^{2}=0,492 ; \lambda_{\text {пв }}=0,10 ; S_{\mathrm{y}}=0,22$ i $k_{\text {д }}=$ 0,492 ;

- за межами колишнього СРСР:

$$
\lambda_{\mathrm{q}}=4,78-0,153 m_{\text {пр }}
$$

при $r=-0,434 ; \eta=0,434 ; R^{2}=0,188 ; \lambda_{\text {пв }}=0,12 ; S_{\mathrm{y}}=0,53$ i $k_{\text {д }}=$ 0,188 ,

де $\lambda_{\text {пв }}$ - показник оцінювання вирівнювання експериментальних значень результативної ознаки, що являє відношення основної помилки вирівнювання до середнього значення результативної ознаки;

$S_{\text {у }}$ - помилка рівнянь (1) і (2) прямолінійної залежності, яку визначали за значеннями коефіцієнтів кореляції між $\lambda_{\mathrm{q}}$ i $m_{\text {пр }}$ та середніми квадратичними відхиленнями відповідних розподілів $\lambda_{\mathrm{q}}$; $k_{\text {д }}$ - коефіцієнт детермінації, що визначає силу впливу маси причепів $m_{\text {пр }}$ на їхню питому вантажопідйомність $\lambda_{q}$.

Показник оцінювання вирівнювання $\lambda_{\text {пв }}$ експериментальних значень $\lambda_{\mathrm{q}}$ першого розподілу причепів залежно від $m_{\text {пр }}$ рівнянням прямої за розрахунками не перевищував 0,10 , що характеризує задовільне вирівнювання. Дещо більшим було значення показника $\lambda_{\text {пв}}$, який дорівнював 0,12 i характеризував вирівнювання експериментальних значень $\lambda_{\mathrm{q}}$ стосовно другого розподілу причепів.

Середні арифметичні значення питомої вантажопідйомності причепів першої і другої груп перевищують помилки відповідних рівнянь регресії відповідно у 10,3 і 8,1 раза. За значеннями коефіцієнтів детермінації маса причепів першої і другої груп відповідно майже на 50 і близько на $20 \%$ причинно зумовлює варіацію вантажопідйомності досліджуваних транспортних засобів. 


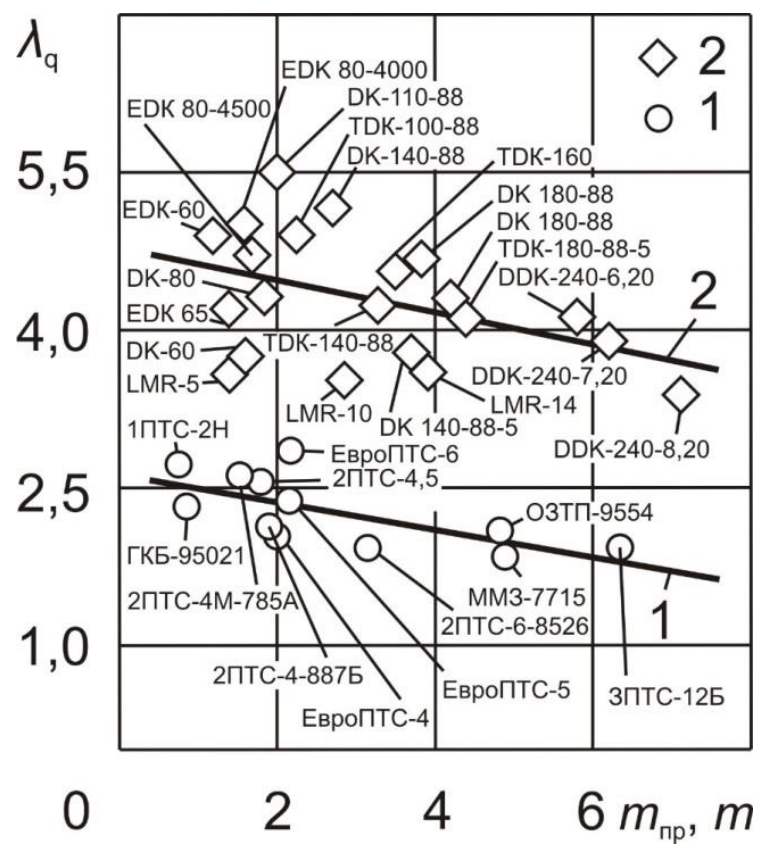

Рис. - Зміна питомої вантажопідйомності $\lambda_{q}$ тракторних причепів залежно від їх маси $m_{\text {пр }} 1$ - причепи виробництва підприємствами колишнього СРСР; 2 - причепи виробництва підприємствами поза межами колишнього СРСР.

Висновки. За вільними членами опрацьованих рівнянь регресії опосередковано можна вважати, що усереднено причепи зарубіжного виробництва у порівнянні з «вітчизняними» мають в 1,82 раза більшу питому вантажопідйомність. За значеннями кутових коефіцієнтів рівнянь і за їх графічним поданням можна зробити і такий висновок, що інтенсивність зменшення питомої вантажопідйомності залежно від маси причепів майже однакова для транспортних засобів, що їх виготовляють різні виробники. Це слід враховувати при проектуванні та виробництві тракторних причепів 3 метою зменшення їхньої матеріало- і металомісткості, що сприятиме екологоспрямованому їх використанню на перевезенні вантажів і в тому числі льонотрести.

\section{Література}

1. Дідух В.Ф. Збирання та первинна переробка льону- 
довгунця: монографія / Дідух В.Ф., Дударєв I.M., Кірчук Р.В. Луцьк: РВВ Луцького НТУ, 2008. - 215 с.

2. Мацепуро М.Е. К вопросу разработки подвижного состава сельскохозяйственного транспорта / М.Е. Мацепуро // Вопросы земледельческой механики. - Минск: Гос. изд-во БССР (Редакция с.-х. литературы), 1959. - Т.1. - С. $230-283$.

3. Завалишин Ф.С. Основы расчета механизированных процессов в растениеводстве / Завалишин Ф.С. - М.: Колос, 1973. 319 c.

4. Диденко Н.К. Обоснование грузоподъемности транспортных средств / Н.К. Диденко // Математические методы прогнозирования сельскохозяйственного производства: прогнозирование развития материально-технической базы. - К.: УкрНИИНТИ, 1970. - Вып. 3. - С. 31 - 33.

5. Семкович А.Д. Об определении оптимальной грузоподъемности транспортных средств для снабжения удобрителей жидкими удобрениями / А.Д. Семкович // Оптимальное проектирование сельскохозяйственных производственных процессов: науч. труды; под ред. В.А. Желиговского. - М.: Колос, 1971. - С. 162 - 178.

6. Лімонт А.С. Вантажопідйомність і розміри кузовів тракторних причепів / А.С. Лімонт // Вісн. Харків. нац. техн. ун-ту с. г. ім. Петра Василенка: механізація с.-г. виробництва. - Х., 2012. - Вип. 124, Т.1. - С. $110-120$.

7. Лимонт А.С. Прогнозирование массово-размерных параметров тракторных процесов // А.С. Лимонт // Техническое обеспечение инновационных технологий в сельском хозяйстве: сб. науч. ст. Междунар. науч.-практ. конф. (Минск, 21-23 ноября 2018 г.) / Мин-во сельского хозяйства и продовольствия республики Беларусь, Белорусский гос. аграр. техн. ун-т / ред. кол.: В.П. Чеботарев [и др.]. - Минск: БГАТУ, 2018. - С. 396 - 399.

8. Лімонт А.С. Енергомісткість технічних засобів готування i збирання рошенцевої льонотрести / А.С. Лімонт // Вісн. Дніпропетр. держ. аграр.-економ. ун-ту. - Дніпропетровськ, 2016. - № 2 (40). С. $44-46$.

9. Дмитриев Е.А. Математическая статистика в почвоведении: учеб. пособ. / Дмитриев Е.А. - М.: Изд-во Москов. ун-та, 1972. 292 c.

10. Герасимович А.И. Математическая статистика: [учеб. пособ. для инж.-техн. и эконом. спец. втузов] / Герасимович А.И. Минск: Вышэйш. шк., 1983. - 279 с. 